\title{
CONCEPTUAL MODELING AS AN APPROACH TO DESIGNING A SUSTAINABLE TOURISM DEVELOPMENT LEARNING PROGRAMME
}

\author{
ELENI DIDASKALOU \\ Department of Business Administration, University of Piraeus, Greece
}

\begin{abstract}
This paper deals with the use of concept models in the learning process. A concept model represents visually one or more aspects of the structure, the properties or the behaviour of a system in a specific field of interest. Concept modeling is directly associated with the learning activity. In a modern system of education (formal or non-formal) learners (pupils, university students, trainees, etc.) must be motivated to participate actively in the learning process so that they can fully develop their skills and abilities. The implementation of active learning techniques leads to a productive non-sterile memorization of knowledge and to its simple automatic/instinctive recall as well as to a potential application of the knowledge gained in class to real life contexts, thus improving the decision-making process. The qualitative concept mapping tools include concept maps that contribute to a more substantial rather than superficial incorporation of the new knowledge in the cognitive structure of the subjects. Within the framework of this study, the methodology of conceptual mapping was employed. Through the use of the computing environment of a concept map construction, the CmapTools software, it was applied to the subject area of sustainable tourism development. The proposed approach may have a significant impact on designing and running courses in the area of sustainable tourism development, satisfying specific training needs. It can also be used not only by those who have the responsibility to procure, design and deliver courses but also by people involved in the tourism policy-making.

Keywords: sustainable tourism development, concept maps, meaningful learning, curriculum design.
\end{abstract}

\section{INTRODUCTION}

In recent decades, tourism has become one of the fastest growing economic sectors in the world which continues to grow and to differentiate so as to meet the needs of a very competitive market. International tourist arrivals grew by a remarkable 7\% in 2017 to reach a total of 1,322 million, plus, many new destinations are constantly emerging [1], [2]. The rapid development of tourism can significantly affect the quality of the environment, natural and man-made, where tourism activity appears. As a result, tourism academics and practitioners pay increasing attention to sustainable tourism development, as a desirable objective of tourism policy and practice [3]. Butler [4] points out that in many cases confusion arises as specific forms of tourism, such as 'alternative' tourism, are a priori considered to be in agreement with the principles of sustainable development. Sustainability is a complex concept, and therefore as requires more comprehensive analysis it needs to be conceptualized meaningfully so that individuals, stakeholders and social groups will be able to implement the basic principles of sustainability [5]. Therefore, it is easily implied that the concept of sustainable tourism development is also a complex one and must be conceptualized in a more comprehensive way.

Many organizations and institutions develop various courses to help understand more efficiently how tourism can be developed sustainably. The paper is suggesting a way of visualizing the idea of sustainable tourism development using the technique of concept maps, which, subsequently, can be used for better planning and design of outcomes-based learning programmes. This way all stakeholders will be able to apply in practice the principles of 
sustainable tourism development. The concept map will be created using the tool CmapTools [6], which is available for free.

\section{MEANINGFUL LEARNING AND CONCEPT MAPS}

In recent years the role of learning is particularly important, for one to be able to cope with the constant changes of a competitive environment. Nowadays many researchers focus on constructivist approaches where the conceptualization of knowledge and how knowledge is constructed by learners themselves plays a key role [7]. It is also argued that new mindsets and practices about learning must be developed emphasizing on an alternative approach to knowledge [8]-[11].

Today the changes of cognitive structures are the center of interest, and learning is viewed as a search for meaning. By understanding how the learner is attempts to construct meaning, educators and institutions can design and develop a curriculum that will promote students' learning [12]. Furthermore, as learning is considered to be a continuous, dynamic and selfregulating process of organizing and changing one's conceptual shapes, which are depended on one's experiences, beliefs and preconceived conceptual shapes, the layout of the learning environment (context, trainer, tools) and socio-cultural interactions play a significant role. According to Mezirow [13] new information to become meaningful must be incorporated by the learner into an already well-developed symbolic frame of reference, an active process involving thought, feelings, and disposition. The learner may also have to be helped to transform his or her frame of reference in order to fully understand the experience. Meaningful learning induces a well-structured, correlated system of concepts and propositions in one's cognitive structure, creating the necessary conditions of implementing new knowledge in future situations. When planning and designing an outcomes-based learning programme, an institution or a curriculum and a learning materials designer, ought to keep in mind that the offered programme has to incorporate the processes that enable deeper understanding, discovery, or transformative change.

Novak [14] points out that the knowledge we already possess consists of networks of concepts and propositions. He defines concepts as perceived regularities in events or objects, or records of events or objects designated by a label (usually a word). All concepts are an abstraction, a representation of reality in our minds, not the reality itself. Concepts are combined to form statements or propositions. The meaning of concepts derives from the totality of propositions linked to any given concept, plus emotional connotations associated with these concepts, derivative in part of the experiences, and context of learning during which the concepts were acquired. But the need to show explicitly how new concepts and propositions were integrated into the learner's cognitive structure led to the development of the concept map tool in the early 1970s based on psychological views and the theory of meaningful learning by Ausubel [15]. As the process of constructive learning advances, new concepts are incorporated into our cognitive structure to a greater or lesser extent, depending on how much effort we are putting into this direction and the quantity and quality of our existing, relevant cognitive structures.

According to Jonassen et al. [16], the models that 'one constructs reflect his conceptual change as it occurs and provide evidence of the growth and reorganization of learners' conceptual models. A method for assessing conceptual change is concept maps [17]. Concept maps constitute a technique for visually representing the structure of information. It basically consists of two types of elements: nodes and links (representing concepts and relations) [18]. Concepts, usually enclosed in circles or boxes of some type, and relationships between concepts indicated by a connecting line linking two concepts words on the line, referred to as linking words or linking phrases, specify the relationship between the two concepts. A 
concept is defined as a perceived regularity in events or objects, or records of events or objects, designated by a label. The label for most concepts is a word, although sometimes symbols such as + or $\%$ can be used and sometimes more than one word is used. Propositions are statements about an object or event in the universe, either naturally occurring or constructed. Propositions contain two or more concepts connected using linking words or phrases to form a meaningful statement. Sometimes these are called semantic units, or units of meaning. Fig. 1 gives an example of a concept map that describes the structure of concept maps and illustrates the above characteristics [19]. A tool for constructing concept map is CmapTools, which creates concept maps that can serve as a "backbone" for a learner's emerging knowledge model for any given domain of study [6], [15].

Concept maps can be used not only for improvement of learning and teaching in classrooms but also as an example illustrating the structure of an entire curriculum. Moreover, it could help students to understand the purpose and the goals of a course as well as the specific technical content of a course even more as a tool for designing curriculum that leads to intended learning outcomes [20]-[23].

\section{DESIGNING A LEARNING PROGRAMME FOR SUSTAINABLE TOURISM DEVELOPMENT}

Recognizing the role of tourism in the development of the countries in which it takes place there is a need to plan tourism development. The most important reasons for the planning and management of tourist destinations are the following: 1) the results of hitherto unplanned tourism development; 2) the study and research of the impacts of tourism development;

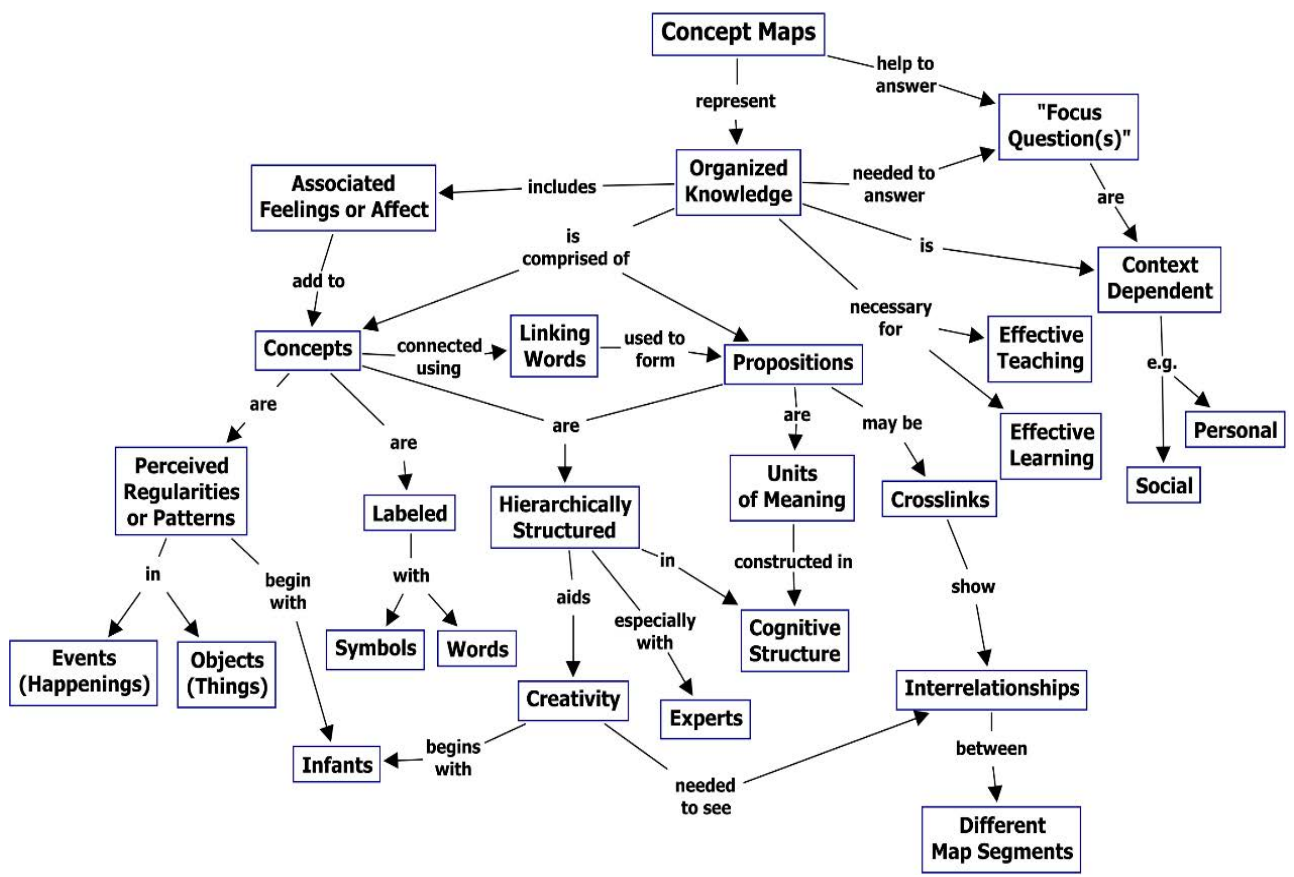

Figure 1: A concept map showing the key features of concept maps. Concept maps tend to be read from the top downwards. (Source: Novak \& Canas, 2006 [19].) 
3) the increasing economic importance of the tourism sector; 4) new data on characteristics and tourism demand, which acquire an "environmental" orientation; and 5) interest in scientific planning and analysis of the development of tourism [24]. It must also be mentioned that tourist destinations are trying to diversify their product to meet the ecologicallydemanding visitors' requirements [25].

A key factor in promoting sustainable tourism development is education for the reason that sustainable principles should be part of an overall plan which subsequently will result in lessening environmental, cultural and social impacts and maximising benefits for local communities. Several studies point out that the lack of an appropriate knowledge base prevents eco-friendly activities [26]. Environmental awareness is also constrained by various cognitive and emotional obstacles [27]. Training on sustainable tourism issues is a necessary prerequisite, so that all people who are involved in the tourism sector, be able to recognize what they have to implement either at the level of business activity or at the level of tourism policy development.

Developing and creating modern and effective curricula is a rather complex process, as curricula should not only be continuously updated, but also should promote meaningful learning. In order to achieve the aforementioned, conceptual mapping can be used as a curriculum design tool. This will help instructors or curriculum designers to identify the major concepts on a specific subject that trainees should acquire. Furthermore, to highlight ideas, keywords, procedures, skills and attitudes that need to be addressed to meet the needs of all stakeholders involved [28]. When planning a course or a session, driven by outcomebased approach, for sustainable tourism development, care must be taken so as learners be able to transfer sustainable tourism theory to practice. Both the complexity of the tourist phenomenon and the difficulty in comprehending various aspects of the impact of tourism activities, require a very well designed curricula. The study sought to point out major ideas and concepts for educators and instructional designers in order to develop curriculum that will help learners to implement the sustainable tourism philosophy at destination level. For the course planning, three concept maps were gradually piecing together.

The general objectives of a learning programme on the specific topic could be:

- Understanding the benefits and problems arising from the development of tourism at the level of the economy, the society and the environment.

- Encouraging a personal commitment to promote policies that maximize the benefits of tourism development at all three levels (economy-society-environment).

- Assisting local managers to adopt effective planning and to make better management decisions.

Taking into account the relevant literature, key concepts were identified and three conceptual maps have been developed, as a guide to design the curriculum of a learning programme in the area of sustainable tourism management at destination level [29]-[33]. The structure of the expansion of the concept maps is given in Fig. 2. It should be noted that the expansion of a map continues until the creator feels that the area he or she wants to describe is adequately explained by the map and reflects to a certain extent the physical acquisition of knowledge.

Additionally, in Figs 3, 4 and 5 the concept maps for Tourism Development, Sustainable Tourism Development and Sustainable Tourism Descriptors, with emphasis on descriptors for destinations, respectively, are given. 


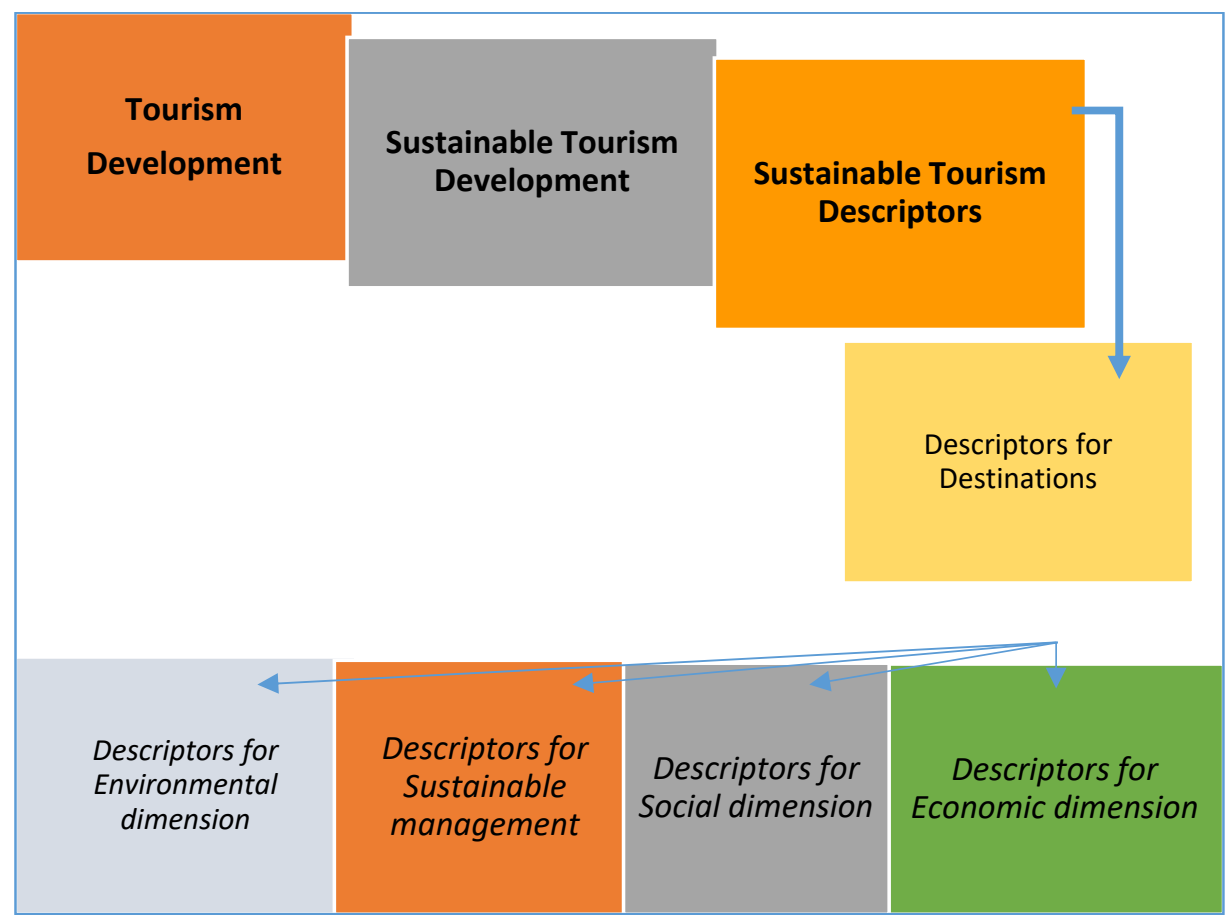

Figure 2: The frame of the three connected concept maps.

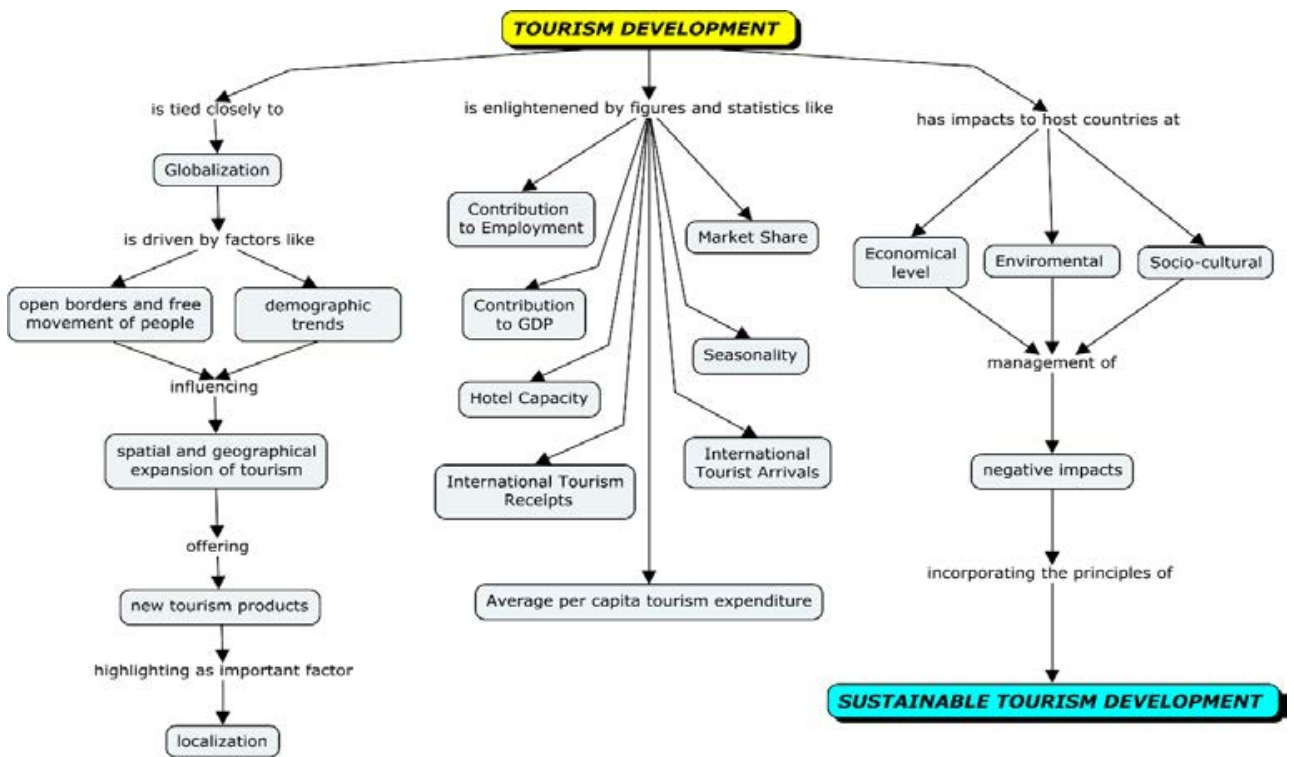

Figure 3: Concept map about Tourism Development. 


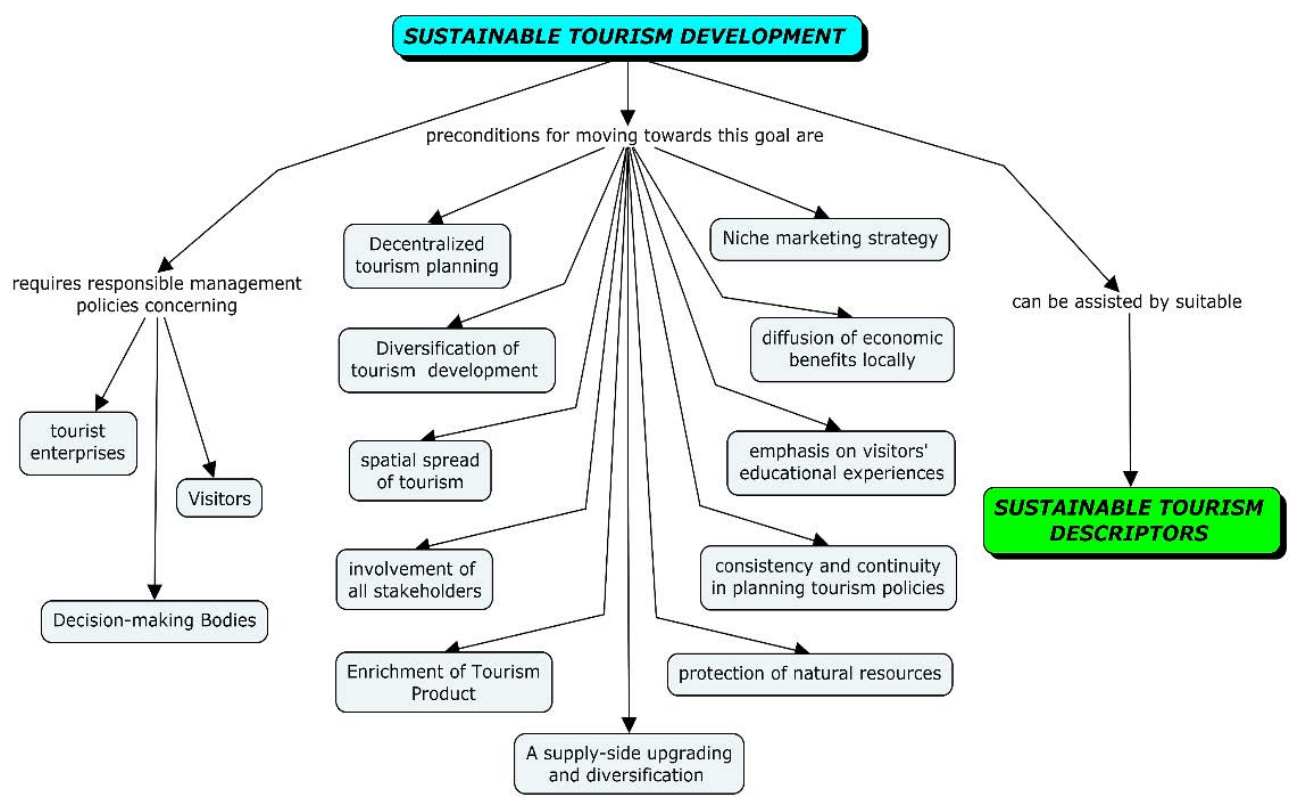

Figure 4: A Sustainable Tourism Development concept map that could be accessed by linking it to the "Tourism Development" concept map in Fig. 3.

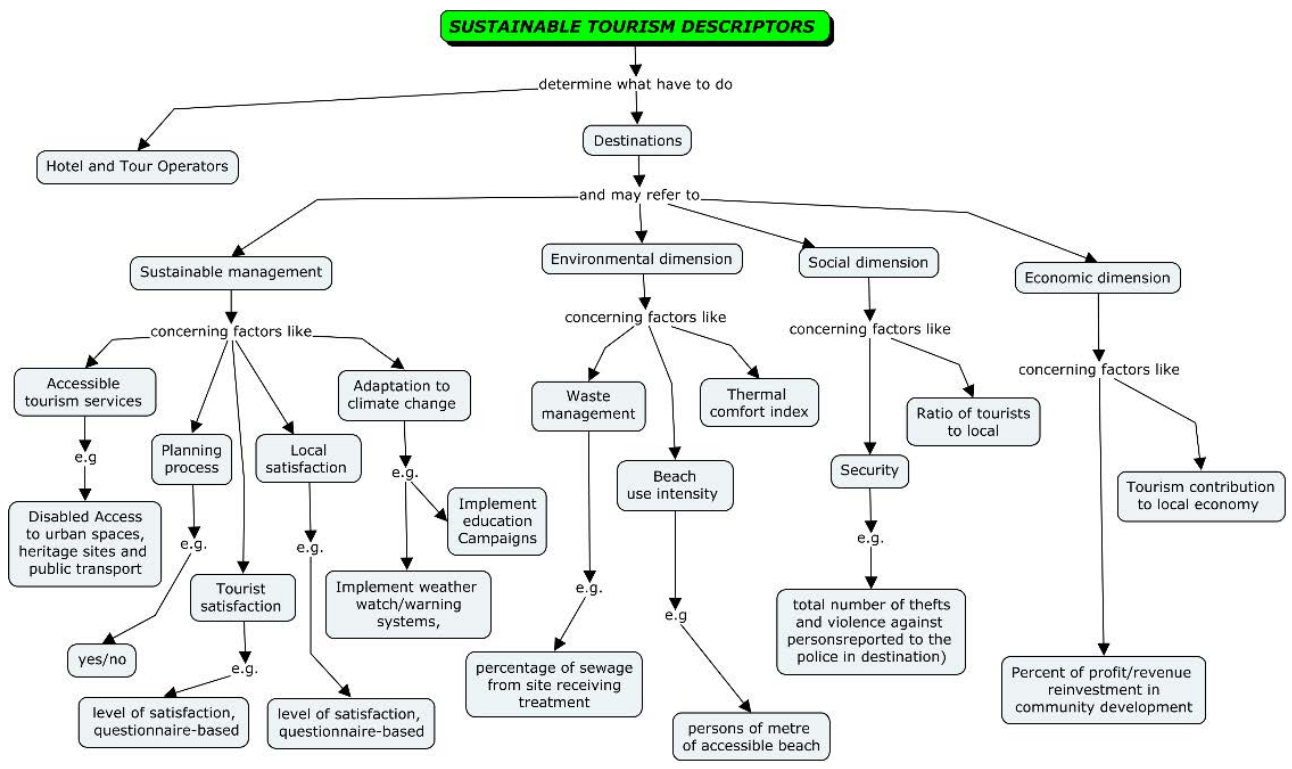

Figure 5: A Sustainable Tourism Descriptors concept map that could be accessed by linking it to the "Sustainable Tourism Development" concept map in Fig. 4. 


\section{FINAL REMARKS}

In the learning society, learning processes should be designed in such a way that learners can learn effectively. Instructors should not only transmit knowledge but also motivate learners to become involved with more engagements than passive listening. Also it should be noted that latest features on scientific and technological issues have a significant impact on education as the new social and economic reality demonstrates the primary role of knowledge as a key component of personal and social development.

This new reality is a challenge for modern society as it should combine knowledge and innovation in order to transform into a learning society. Learning is a crucial factor in the development of society (economic growth, social prosperity, and personal fulfillment), helping to ensure a sustainable planet. However, in order to fulfill this role, learning has to be organized into a different set of principles. Concept maps, developed by Novac based on the theory of Ausubel, is a technique for visualizing knowledge. It is also used for the emergence of these representations that one learns by using graphs in a network form. Conceptual maps were initially used in education, but today their applications are constantly expanding covering all the levels of the educational processes as well as the field of business.

Furthermore, concept maps provide a useful way of designing and developing an effective curriculum. Their utilization may clarify the important concepts that should be included into a curriculum of a particular subject area so that learners acquire the fundamental and essential conceptual background required to develop or improve their skills and abilities, which they can use effectively in their professional field. Conceptual mapping has been enhanced by the development of appropriate software. CmapTools is a fairly widespread conceptual mapping software.

Taking into account that tourism is an important pillar of the development of Greece, education in tourism must be linked to real or perceived needs of the tourism industry. Nowadays, sustainable tourism development must be a part of any course syllabus on tourism development. The paper introduced a framework for curriculum planners on improving tourism education. It is not claimed that all issues are taking account, on the contrary, it is an attempt to clarify important concepts that a learning programme should include for those involved in the tourism policy planning processes on sustainable tourism development. The conceptual mapping technique using the CmapTools software was used to develop the specific curriculum.

\section{ACKNOWLEDGEMENT}

The author would like to express her thanks to the Research Center of University of Piraeus for partially funding the present work.

\section{REFERENCES}

[1] 2017 International Tourism Results: The highest in seven years, UNWTO World Tourism Barometer. Online. http://cf.cdn.unwto.org/sites/all/files/pdf/unwto_ barom18_01_january_excerpt.pdf. Accessed on: 2 Feb. 2018.

[2] UNWTO Tourism Highlights: 2017 Edition. Online. www.e-unwto.org/doi/pdf/ 10.18111/9789284419029. Accessed on: 2 Feb. 2018.

[3] Sharpley, R., Tourism and sustainable development: Exploring the theoretical divide. Journal of Sustainable Tourism, 8(1), pp. 1-19, 2000.

[4] Butler, R., Sustainable tourism: A state-of-the-art review. Tourism Geographies, 1(1), pp. 7-25, 1999. 
[5] Lu, J. \& Nepal, S., Sustainable tourism research: an analysis of papers published in the Journal of Sustainable Tourism. Journal of Sustainable Tourism, 17(1), pp. 5-16, 2009.

[6] IHMC, https://cmap.ihmc.us/.

[7] Katzlinger, E. \& Herzog, M., Interuniversity collaborative learning with Wiki toolsets. Proceedings for the 12th European Conference on eLearning: ECEL 2013, pp. 184 190, 2013.

[8] Riegler, A., Constructivism. Paradigms in Theory Construction, ed. L. L'Abate, Springer: New York, pp. 233-255, 2012.

[9] Orman, T.F., "Paradigm" as a central concept in Thomas Kuhn's Thought. International Journal of Humanities and Social Science, 6(10), pp. 47-52, 2016.

[10] Cavalo, D., Models of growth - towards fundamental change in learning environments. BT Technology Journal, 22(4), pp. 96-112, 2004.

[11] Kuhn, T.S., Second thoughts on paradigms. The Structure of Scientific Theories, 2nd ed., ed. F. Suppe, University of Illinois Press: Urbana, pp. 459-482, 1997.

[12] Weegar, M.-A. \& Pacis, D.A., Comparison of two theories of learning - Behaviorism and constructivism as applied to face-to-face and online learning. CASA E-LEADER Conference Manila, Philippines, 2012. Online. www.g-casa.com/conferences/manila/ papers/Weegar.pdf. Accessed on: 3 Feb. 2018.

[13] Mezirow, J., Transformative learning: Theory to practice. New Directions for Adult and Continuing Education, 74, pp. 5-12, 1997.

[14] Novak, J. Meaningful learning: The essential factor for conceptual change in limited or appropriate propositional hierarchies leading to empowerment of learners. Science Education, 86(4), pp. 548-571, 2002.

[15] Novak, J., Learning, creating, and using knowledge: Concept maps as facilitative tools in schools and corporations. Journal of e-Learning and Knowledge Society, 6(3), pp. 21-30, 2010.

[16] Jonassen, D., Strobel, J. \& Gottdenker, J., Model building for conceptual change. Interactive Learning Environments, 13(1-2), pp. 15-37, 2005.

[17] Edmundson, K.M., Assessing science understanding through concept maps. Assessing Science Understanding: A Human Constructivist View, eds J.J. Mintzes, J.H. Wandersee \& J.D. Novak, Academic Press: San Diego, pp. 19-40, 2000.

[18] Lanzing, J., Everything you always wanted to know about Concept Mapping. Cognitive Support for Learning: Imagining the Unknown, ed. P. Kommers, IOS Press: Amsterdam, pp. 47-72, 2004.

[19] Novak, J. \& Canas, A., The theory underlying concept maps and how to construct and use them. Technical Report IHMC CmapTools 2006-01 Rev 01-2008. Online. https://cmap.ihmc.us/docs/theory-of-concept-maps. Accessed on: 10 Feb. 2018.

[20] Cornwell, P.J., Concept maps in the mechanical engineering curriculum. 1996 ASEE Annual Conference Proceedings, Washington, District of Columbia. Online. https://peer.asee.org/5933. Accessed on: 10 Feb. 2018.

[21] Tembe, B.L. \& Kamble, S.K., Use of concept maps as an assessment tool in mechanical engineering education. Journal of Learning in Higher Education, 9(1), pp. 127-134, 2013.

[22] McDaniel, E., Roth, B. \& Millar, M., Concept mapping as a tool for curriculum design, Issues. Informing Science and Information Technology Education Joint Conference, Flagstaff, USA, pp. 505-513, 2005. 
[23] Katagall, R., Dadde, R., Goudar, R.H. \& Rao, S., Concept mapping in education and semantic knowledge representation: An illustrative survey. Procedia Computer Science, 48, pp. 638-643, 2015.

[24] Kokkosis, C. \& Tsartas, P., Sustainable Tourism Development and the Environment, Kritiki: Athens, pp. 91-95, 2001 (in Greek).

[25] Hassan, S., Determinants of market competitiveness in an environmentally sustainable tourism industry. Journal of Travel Research, 38(3), pp. 239-245, 2000.

[26] Boo, S. \& Park, E., An examination of green intention: The effect of environmental knowledge and educational experiences on meeting planners' implementation of green meeting practices. Journal of Sustainable Tourism, 21(8), pp. 1129-1147, 2013.

[27] Kollmuss, A. \& Agyeman, J., Mind the gap: Why do people act environmentally and what are the barriers to pro-environmental behavior? Environmental Education Research, 8(2), pp. 239-260, 2002.

[28] Isaacs, J., Concept-mapping software: How effective is the learning tool in an online learning. environment? Online. www.informationtamers.com/PDF/Concept-Mapping _Software_-_How_effective_is_the_learning_tool_in_an_online_learning environment.pdf. Accessed on: 10 Feb. 2018.

[29] Swarbooke, J., Sustainable Tourism Management, CAB International: Wallingford, pp. 13-23, 1999.

[30] Weaver, D., Sustainable Tourism, Routledge: Oxford, pp. 18-37, 2006.

[31] Choi, H.C. \& Turk, E.S., Sustainability indicators for managing community tourism. Tourism Management, 27(6), pp. 1274-1289, 2006.

[32] UNWTO, Sustainable tourism indicators and destination management, Regional Workshop, Kolašin, Montenegro, 2007. Online. http://sdt.unwto.org/sites/all/files/ pdf/finrep.pdf. Accessed on: 10 Feb. 2018.

[33] EU, The European Tourism Indicator System, 2016. Online. http://ec.europa.eu/ growth/sectors/tourism/offer/sustainable/indicators_el. Accessed on: 10 Feb. 2018. 